\title{
Epidemiological Outbreak Investigation of Chickenpox in Baidauli VDC, Nawalparasi, Nepal
}

\author{
Ram Chandra Poudel, ${ }^{1}$ Sabika Munikar, ${ }^{2}$ Biswanath Acharya, ${ }^{3}$ Gambhir Shrestha, ${ }^{4}$ Kanchan Thapa ${ }^{4}$ \\ ${ }^{1}$ District Public Health Office (DPHO), Ministry of Health and Population (MoHP), Nawalparasi, Nepal, ${ }^{2}$ Om Health \\ Campus, Gopikrishna Nagar, Chabahil, Kathmandu, Nepal, ${ }^{3}$ Thammasat University, Bangkok, Thailand, ${ }^{4}$ Department of \\ Cancer Prevention, Control and Research, B.P. Koirala Memorial Cancer Hospital, Bharatpur, Chitwan, Nepal, ${ }^{5}$ Central \\ Department of Popoulation Studies (CDPS), Tribhuvan University, Kirtipur, Nepal.
}

\begin{abstract}
Background: On 2015, a cluster of chickenpox like symptoms was reported in Baidauli VDC of Nawalparasi, Nepal. This study aims to report the outbreak investigation and guide preventive and control measures. Methods: This investigation was conducted in Baidauli VDC of Nawalparasi, Nepal where a large number of cases with infectious rashes with fever was reported. Data were collected using a semi-structured questionnaire comprising of socio-demographic characteristics and clinical features. A detailed clinical examination of the cases was also performed. The outbreak was described by time, place and person and the epidemiological curve drawn. Results: A total of 55 cases from 27 households were affected by chickenpox. The outbreak continued for 45 days. The number of cases peaked $(n=25)$ one month after detection of the primary case. The last case was reported after 15 days of the peak. The commonest age group affected was 5 to 15 years with a mean of 11.3 years (SD 8.9). The mean duration of rashes was 7.2 days (SD 1.7) which ranged from 3 days to 12 days. All the cases had rashes on head/face, trunk, arm and legs, and some had rashes inside the mouth $(\mathrm{n}=8)$ and palm $(\mathrm{n}=5)$. Almost $95 \%(\mathrm{n}=52)$ cases experienced fever. Conclusions: This study concluded that there was an outbreak of chickenpox. The signs and symptoms of the disease were due to chicken pox infection. Immediate preventive and control measures were recommended to halt the spread of the disease. Health education and awareness regarding the preventive measures of disease should be promoted.
\end{abstract}

Keywords: chickenpox; epidemics; outbreak investigation.

\section{INTRODUCTION}

Chickenpox is regarded as a benign, self-limiting illness of children, caused by the Varicella Zoster Virus (VZV) and usually last for 5 to 7 days. ${ }^{1,2}$ It is airborne or droplet transmission with secondary attack rates in susceptible household contacts of greater than $8.5 \%{ }^{3-5}$ Though it does not have life threating complication but there are chances of adverse consequences in later life with past history of chickenpox. ${ }^{6}$ Vaccination for varicella is available for children in developed countries. ${ }^{7,8}$

Even with decreasing trend of chickenpox in developed countries due to vaccination, ${ }^{9}$ a chickenpox vaccine yet to be administered in Nepal ${ }^{10}$ and hence developing countries like us still pose risk to be suffered from such diseases. ${ }^{4}$ The objectives of this study are to report the outbreak investigation of Chickenpox like symptoms in Baidauli VDC of Nawalparasi, Nepal and to guide preventive and control measures in future. The management of cases was of first priority with symptomatic treatment in low resource settings.

\section{METHODS}

A descriptive cross-sectional study was conducted among the affected population of infectious rashes in Baidauli VDC, Nawalparasi, Nepal. The outbreak investigation was carried out after the report of the appearance of the first case. A clinical case/possible case was defined as one with acute onset of diffuse (generalized) fluid-filled vesicular or maculo-papular rash having fever without apparent cause occurring after $6^{\text {th }}$ December 2015. A semi-structured questionnaire was developed and used to collect data regarding demographic and clinical details of cases. A detailed clinical examination was done to evaluate the disease condition. Line listing of each case was done in terms of time, place and person. All the collected data were entered and analyzed in Microsoft Excel 2007. Data were summarized in terms of percentage, mean, standard deviation, frequency distribution tables and graphical methods of presentation of data including the epidemic curve. Ethical approval was taken from Nepal Health Research Council prior to conduction of study.

Correspondence: Kanchan Thapa, Central Department of Popoulation Studies (CDPS), Tribhuvan University, Kirtipur, Nepal. Email: kanchanraj3@gmail.com. Phone: +977-985118132. Article received: 2019-03. Article accepted: $2019-08-02$. 
Poudel et al. Epidemiological Outbreak Investigation of Chickenpox in Baidauli VDC..

\section{RESULTS}

A total of 55 persons were affected by infectious rashes, which was higher than that in the same area during the previous years. Thus, the episode was considered an outbreak. The first case developed illness on 6th December 2015; the secondary case was reported only after one week after the primary case (Figure 1).

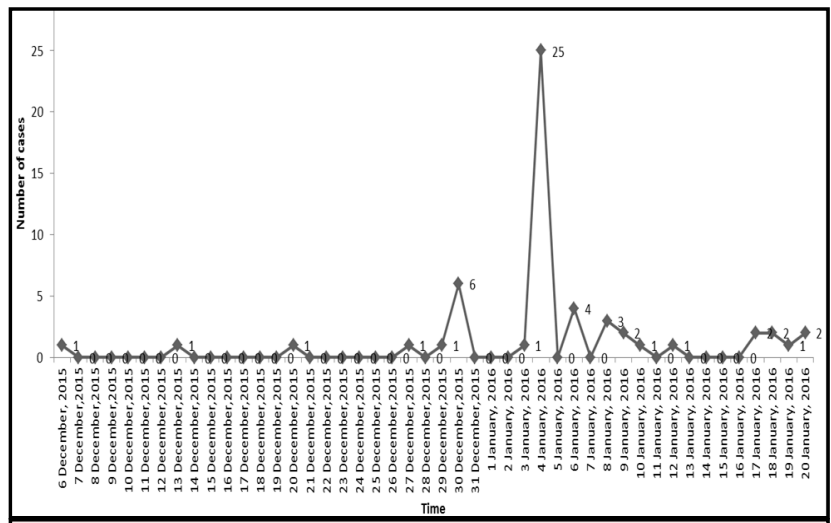

Figure 1. Distribution of number of cases reported by time in Baidauli VDC of Nawalparasi $(n=55)$.

The earliest rash onset was in a male of 33 years. He was a businessman with a frequent history of travelling to India. His rashes consisted of many (more than 500) pruritic vesicular lesions of 7 days duration on the whole body including on palms and mouth but not on soles. He also had a fever for few days. He could not recall any potential exposure to varicella in the weeks before rash onset. The secondary case also appeared in his family. All family members (five) except his wife were infected with chickenpox. Since the first case was reported on the first week of December; this indicates that the exposure of the patients to the virus was in the last week of November 2015. The incubation period of chickenpox is 10 to 21 days with an average of 14 to 16 days. Outbreak reached to the peak on 4th January 2016. Then, outbreak rapidly declined and the last cases reported were on $20^{\text {th }}$ January 2016. The total period of the outbreak was 45 days. The cases were reported on ward number 1, 3, 7, 8 and 9 of Baidauli VDC (Table 1).

\begin{tabular}{|cc|}
\hline $\begin{array}{l}\text { Table 1. Distribution of number of cases in different } \\
\text { affected } \\
(\mathbf{n = 5 5 )} \text {. }\end{array}$ & \begin{tabular}{c} 
wards of Baidauli VDC of Nawalparasi \\
\hline Ward Number
\end{tabular} \\
\hline 1 & $9(16.4)$ \\
3 & $1(1.8)$ \\
7 & $13(23.6)$ \\
8 & $20(36.4)$ \\
9 & $12(21.8)$ \\
\hline
\end{tabular}

A total of 27 households was affected by the illness and an average of 2 cases per household was reported, which ranged from one to six cases per household (Table 2). The mean age of the cases was $11.27(\mathrm{SD}=8.94)$ years. The majority $(82 \%)$ of the

\begin{tabular}{|cc|}
\hline $\begin{array}{c}\text { Table 2. Household distribution of cases in Baidauli } \\
\text { VDC of Nawalparasi. }\end{array}$ \\
\hline $\begin{array}{c}\text { Number of Household } \\
(\mathbf{n}=\mathbf{2 7})\end{array}$ & Number of Cases $(\mathbf{n}=\mathbf{5 5})$ \\
1 & 6 \\
2 & 5 \\
2 & 4 \\
2 & 3 \\
5 & 2 \\
15 & 1 \\
\hline
\end{tabular}

cases fall in the age group 5 to 15 years. There was an almost equal proportion of gender affected by the illness. Regarding ethnicity, it was found that $60 \%$ of cases were Terai originated Brahmin/ Chhetri. About $71 \%$ of cases were vaccinated for routine vaccination and $29 \%$ of cases were not (Table 3).

\begin{tabular}{|c|c|}
\hline $\begin{array}{l}\text { Table 3. Distribution of } \\
\text { characteristic of cases in } \\
\text { Nawalparasi }(n=55) \text {. }\end{array}$ & $\begin{array}{l}\text { sociodemographic } \\
\text { Baidauli VDC of }\end{array}$ \\
\hline Characteristics & n (\%) \\
\hline \multicolumn{2}{|l|}{ Age (years) } \\
\hline$>5$ & $1(1.8)$ \\
\hline $5-15$ & $45(81.8)$ \\
\hline$>15$ & $9(16.4)$ \\
\hline Mean age \pm SD & $11.27 \pm 8.94$ years \\
\hline \multicolumn{2}{|l|}{ Sex } \\
\hline Female & $25(45.5)$ \\
\hline Male & $30(54.5)$ \\
\hline \multicolumn{2}{|l|}{ Ethnicity } \\
\hline Dalit (Terai) & $14(25.5)$ \\
\hline Janjati (Terai ) & $5(9.1)$ \\
\hline Brahmin/ Chhetri (Terai) & $33(60.0)$ \\
\hline Others & $3(5.4)$ \\
\hline \multicolumn{2}{|l|}{ Status of Routine Vaccination } \\
\hline Completed & $39(70.9)$ \\
\hline Unknown & $16(29.1)$ \\
\hline
\end{tabular}

The mean duration of rashes was $7.23(\mathrm{SD}=1.73)$ days with the majority of the cases (71\%) having rashes for 3 to 7 days. All the cases have macular/ papular lesions, vesicular/blister, and scab, and only five cases experienced itching over their rashes (Table 4).

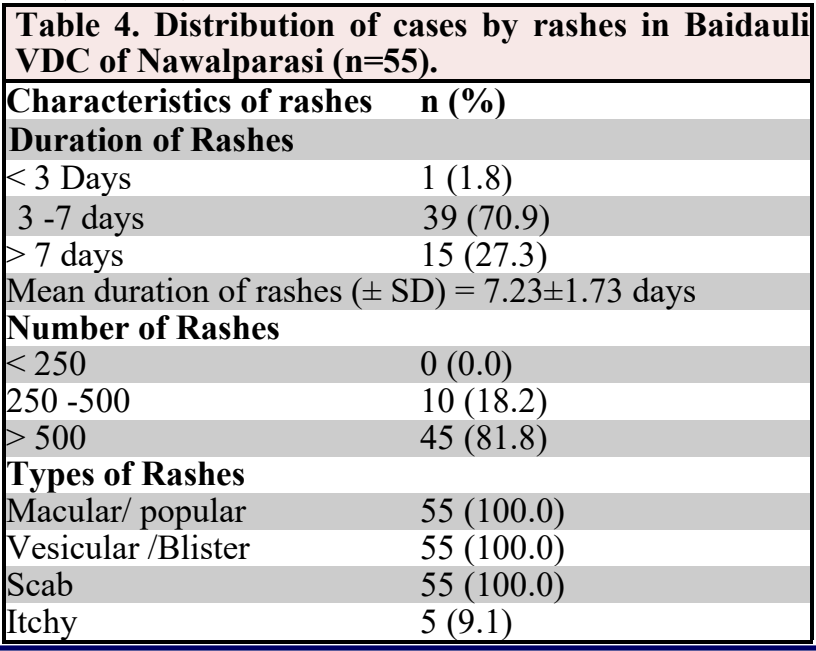


All the cases have rashes over face/head, trunk, arms, and legs, but rashes on buccal mucosa (67\%) and on palms (33\%) were only among cases above 15 years of age (Table 5 ).

\begin{tabular}{|llll|}
\hline $\begin{array}{l}\text { Table 5. Distribution of cases by location of rashes in } \\
\text { different age group in Baidauli VDC of Nawalparasi } \\
\text { (n=55). }\end{array}$ \\
\hline Location & \multicolumn{3}{|c|}{ Age $\mathrm{n}(\%)$} \\
& $<5(\mathrm{n}=10)$ & $5-15(\mathrm{n}=36)$ & $>15(\mathrm{n}=9)$ \\
Face/Head & $10(100.0)$ & $36(100.0)$ & $9(100.0)$ \\
Trunk & $10(100.0)$ & $36(100.0)$ & $9(100.0)$ \\
Arms & $10(100.0)$ & $36(100.0)$ & $9(100.0)$ \\
Legs & $10(100.0)$ & $36(100.0)$ & $9(100.0)$ \\
Inside mouth & 0 & $2(5.6)$ & $6(66.7)$ \\
Palms & 0 & $2(5.6)$ & $3(33.3)$ \\
\hline
\end{tabular}

Most of the cases $(95 \%)$ experienced fever during illness. The mean duration of fever was 3.73 $(\mathrm{SD}=1.73)$ days. The mean duration of illness was 9.45 days $(\mathrm{SD}=3.02)$ with the majority $(82 \%)$ sick for 5 to 10 days. Eight among ten cases reported of not seeking care from health care providers during illness. A quarter of cases reported of skin infections with regard to complications of illness (Table 6). The cases were asked about the causes of the disease. Infected cases reported that they believed that this illness was a state of presences of the goddess in their bodies (i.e. Sarirama Mata Mai Utreko). They thought that if this illness was treated with modern medicine, the goddess would get angry and they would be severely ill. Hence, most of them were not seeking care at health facilities.

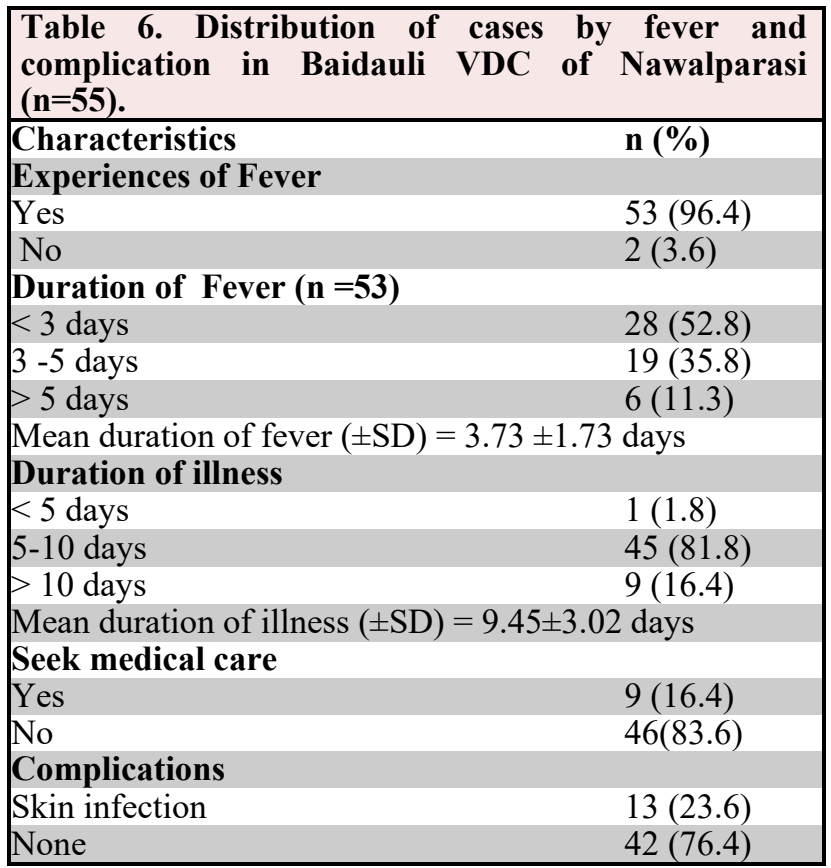

\section{DISCUSSION}

This study is the first to state the largest epidemiological outbreak of chickenpox reported in Nepal. The epidemiological curve in this investigation showed a propagated epidemic. This is in contrast to the study conducted in India where there was no any secondary wave of infection. ${ }^{14}$ The reason might be the settings of the outbreak; the place of the outbreak in Indian study was within the hostel of nurses whereas our study was not limited to a single housing but in a community. In this study, the mean age of the cases was 11.27 years. However, an Indian study reported slightly older mean age 19.87 years. $^{14}$ However, the distribution of disease in the different age groups were found to be similar. ${ }^{15}$ This study supported that adults also suffer from chickenpox similar to the other studies. ${ }^{16,17}$ Since most of the cases were from school going age group; this might have resulted in the outbreak. Cases of mild disease, not recognized as varicella before detection of the outbreak, might have played an important role in virus transmission in this population. All patients with chickenpox should be excluded from schools or day care centres until all lesions have crusted. On routine vaccination as per National Program on Immunization of Nepal, varicella vaccine is not available. ${ }^{10}$ Studies have shown that varicella vaccination can reduce the incidence of chickenpox and also less among the vaccinated cases. $^{15,18,19}$ However, the effectiveness of the vaccine in controversies in some studies. ${ }^{4}$ Most of the cases did not seek medical care from health facilities and some respondents cited that the cause of the disease was the curse of God. Socio-cultural belief is also one of the reasons for not coming to health facilities. This shows a clear need for health education in disease prevention and control. District Health office, Nawalparasi responded quickly and mobilized Rapid Response Team to the affected area. Health education was given to the community via the mobilization of Female Community Health Workers, health workers, and local leaders. Isolation of the cases was done until all the lesions have crusted, which helped to control the epidemic. The limitation of this study was that serological confirmation was not done, only epidemiological and clinical investigations of the cases was done. Serological tests could have detected more cases (mild and subclinical) than those reported by clinical findings. ${ }^{20,21}$

\section{CONCLUSIONS}

Unexpected number of cases of rashes with fever in Nawalparasi was due to Chickenpox. These findings highlighted the importance of case-based reporting of varicella and the exclusion of patients from school and other public places until all lesions crust fade away. Health education and awareness about recognizing patients with mild cases should be disseminated to health-care providers, school administrators and community people.

\section{ACKNOWLEDGEMENTS}

The study team would like to thank District Public Health Office (DPHO), Nawalparasi and Epidemiology and Disease Control Division (DoHS), Teku, Kathmandu. We would like to thank Rashmi Mulmi for editing the manuscript. 


\section{REFERENCES}

1. Center for Disease Control and Prevention. Chickenpox (Varicella) [Internet]. Atlanta (USA). CDC; 2018. [cited 2019 Jan 1].

2. World Health Organization. International travel and health [Internet]. Geneva (Switzerland): WHO; 2018 [cited 2019 Jan 10].

3. Wharton M. The epidemiology of VericellaZoster Virus infections. Infectious Disease Clinics of North America. 1996;10(3).

4. Kadri S, Saleem-ur-Rehman, Rehana K, Gergianaki I. Rising trends of chicken pox outbreaks among school children in Kashmir, India-suggestions for health policy.EC Bacteriology and Virology Research. 2017;2.5 (1):179-90.

5. Ejaz A, Naeem Raza, Sohail M. Outcome of chicken pox in adult immunocompetent patients. Journal of Pakistan Association of Dermatologists. 2006;16(1):141-6.

6. Amirian ES, Scheurer M, Zhou R, Armstrong G, Margaret R,Georgina NA, Dainel L, et al.History of chickenpox in glioma risk: a report from the glioma international case-control study (GICC).Cancer Med. 2016; 5(6):1352-58

7. Bhave SY. Controversies in chicken-pox immunization. Indian J Pediatr. 2003;70(6):5037.

8. Bakker KM, Martinez ME, Helm B, Stevenson TJ. Digital epidemiology reveals global childhood disease seasonality and the effects of immunization.PNAS. 2016;113(24):6689-6694.

9. Center for Disease Control and Prevention. Epidemiology and prevention of vaccine preventable diseases-Varicella. $13^{\text {th }}$ ed. Atlanta (USA): CDC;2015.

10.Ministry of Health and Population. Annual Health Report 2014. Teku (Nepal): Department of Health Services; 2014.

11.Bhandari G, Dixit S, Ghimire U, Maskey M. Outbreak investigation of diarrheal diseases in Jajarkot. J Nepal Health Rese Counc. 2009;7 (2):66-8.
12.Mahato R, Bhandari G, Shrestha J, Basnet P. Pandemic influenza A (H1N1) 2009 outbreak investigation in Nepal. J Nepal Health Rese Counc. 2010;8(2):75-81.

13.Upadhyaya SK, Pradhan PMS, Mahato RK, Marasini B, Shakya G, Baral G, Baral KP. Outbreak investigation of influenza in Pazaru VDC of Jajarkot District of Nepal. J Nepal Health Rese Counc. 2016;14(3):186-91.

14.Bhatti VK, Lee C, Mahadevan C, Gurpreet M, Nath A, Gen M, et al. Use of immunization as strategy for outbreak control of varicella zoster in an institutional setting. Med J Armed Forces India. 2014;0:2-6.

15.Guris D, Jumaan AO, Mascola L, Watson BM, Zhang JX, Chaves SS, et al. Changing varicella epidemiology in active surveillance sites-United States,

1995-2005.

J Infect Dis. 2008;197(s2):S71-5.

16.Luis GR, Agustin JJ, Miguel MB. Shingles and chicken pox in the adult: markers of severity. emergencias. 2012;24(8):277-82.

17. Chowdhury MK, Siddique AA, Haque MM, Ali $\mathrm{S}$, Biswas S, Biswas PK, et al. Life threatening complications of chicken pox in a young adult. $\mathrm{J}$ Medicine. 2014;15(1):55-7.

18.Dworkin MS, Jennings CE, Roth-Thomas J, Lang JE, Stukenberg C, Lumpkin JR. An outbreak of varicella among children attending preschool and elementary school in illinois. Clin Infect Dis. 2002;35(1):102-4.

19. Manuel GC, García M. Impact of universal varicella vaccination in Nigeria 2006-2010.An Sist Sanit Navar. 2011 May-Aug; 34(2):193-202

20.Kuroiwa C, Vongphrachanh P, Xayyavong P, Southalack K, Hashizume M, Nakamura S. Measles epidemiology and outbreak investigation using IgM test in Laos. J Epidemiol. 11(6):255-62.

21.Schmidt NJ, Arvin AM, Martin DP Gard EA. Serological investigation of an outbreak of simian varicella in erythrocebus patas monkeys. J Clin Microbiol. 1983;18(4):901-4.

Citation: Poudel RC, Munikar S, Acharya B, Shrestha G, Thapa T. Epidemiological Outbreak Investigation of Chickenpox in Baidauli VDC, Nawalparasi, Nepal. JCMS Nepal. 2019; 15(3):171-4. 